\title{
Udvikling af vejledning fra tavs viden og privatpraktiserende kultur til italesættelse og institutionalisering
}

\author{
Af redaktorerne af dette nummer: \\ Lotte Rienecker, centerleder ved Akademisk Skrivecenter, Københavns Universitet \\ Mads Hermansen, professor i padagogisk psykologi, CBS.
}

De seneste par år har vi set en bølge af interesse $i$ vejledning, både i form af bøger, efterspørgsel på vejledningskurser, administrativ og politisk interesse for at ‘styrke vejledningsindsatsen' på universiteternes vejledning på skriftlige såvel som andre pædagogiske opgaver. Derfor er dette temanummer også blevet righoldigt. De helt centrale vejledningstemaer dette nummer behandler, er studerendes forventninger til vejledning, ekspliciterede retningslinjer for selve vejledningen og for studerendes arbejde, kriterier for bedommelse af den præstation der vejledes på, og godkendelse som underliggende og styrende for vejledning, vejlednings situering i specifikke kontekster bl.a. fagmiljøer, projekttyper og skriveprocesmæssige kontekster, vejledningsevaluering og først og sidst: Hvordan kvaliteten af tilbuddet om vejledning - den mindst synlige universitetspædagogiske aktivitet - kan udvikles i universitetslærernes travle hverdag.

Nummeret indledes med en artikel af Norges to grand old men i universitetspædagogikken, Per Lauvås (professor ved Høgskolan i Østfold) og Gunnar Handal (professor emeritus ved Oslo Universitet) hyppige kursusholdere om forskningsvejledning, også i Danmark. De argumenterer for at kvalitetsudvikling af vejledning ligger $i$ at vejledere og vejledte må tale om hvad de forventer af hinanden: forhandle, afstemme forventninger og eksplicitere det tavse og implicitte.

\section{Hvad findes der af litteratur om vejledning}

Gitte Wichmann-Hansen (adjunkt), Berit Eika (professor) og Annemette Mørcke (adjunkt, alle ved Enhed for Medicinsk Uddannelse, AU) har foretaget en metastudie af 50 udvalgte stykker empirisk vejledningsforskning, og fundet at "indtil nu har forskningen overbevisende konstateret, at relationen er den mest afgørende faktor for et vellykket vejledningsforløb, men forskningen har til gengæld ikke leveret overbevisende viden om, hvilke pædagogiske kompetencer vejledere bør have, endsige hvordan de trænes og udvikles". Forfatterne anbefaler fremtidig fokus på vejledningsmetoder og -didaktikker, frem for flere selvrapporterende vejledningstilfredsheds-beretninger.

\section{Forventninger til og forventningsstyring af vejledningen}

- har Henriette Lyngstrøm (studieleder på Forhistorisk Arkæologi) undersøgt ved spørgeskemaer. Det har resulteret $i$ udarbejdelse af efterfølgende retningslinjer til studerende og vejledere. Det bemærkelsesværdige resultat var mærkbart ændrede forventninger til mængden af vejledning og hvad vejledning skulle bruges til, fra 2002-2006. Lyngstrøm overraskes over det empiriske fund at specialestuderende vægter vejledernes overholdelse af aftaler og forberedelse til møder højere end deres specifikke, faglige indsigt. Fundet er imidlertid på linje med hvad andre undersøgelser af bestemmende faktorer for valg af vejleder har identificeret (fx Harboe og von Müllen, 2006, Bjerrum, Ellegaard \& Nielsen, 2003): Det er i mindre grad faglige og specialistkompetencer, og i højere grad menneskelige og pædagogiske kvaliteter og generalistkompetencer, studerende efterspørger hos en vejleder. Det er ikke alene ved at være god til 'sit fag' at man får ry for at være og evalueres 
som en god vejleder - eller også skal fag defineres bredt som også indeholdende engagement i studerendes og yngre kollegers arbejde, projektstyring og projektmetoder, informationskompetence og almindelig væren tilgængelig og støttende.

\section{Ekspliciterede retningslinjer for vejledning og for studerendes arbejde}

Studerende med konstruktionsprojekter (som kendes fra mange andre studier end de naturvidenskabelige) kommer let til at nedprioritere det skriftlige arbejde med opgaven/specialet til fordel for arbejdet på deres konstruktion. Ken Friis Larsen og Henning Niss (henh. amanuensis og adjunkt, ITU) har udarbejdet retningslinjer og huskelister for studerende og vejledere der skal fastholde opmærksomheden på det skriftlige produkt som dokumentationen for målrettet, videnskabeligt arbejde. Opgaven er også her det afgørende bedømmelsesgrundlag.

\section{Samarbejde med eksterne samarbejdspartnere}

På en del universiteter og business schools er der rig tradition for at de studerende baserer deres projekter, bacheloropgaver eller specialer på empiri fra virksomheder, organisationer, eller måske endog prøver at fungere som problemknusere eller konsulenter. På fx CBS har det afstedkommet at der er blevet lavet ét helt regelsæt for hvordan samarbejdsaftaler for den slags projekter, specielt for at forhindre konflikter og misforståelser. Men trekanten mellem studerende, virksomhed og vejleder giver også anledning til refleksion over hvordan nu disse situationer vejledningsmæssigt gribes an. Det er dette aspekt som Jens E.Wilhjelm (lektor, studieleder ved DTU) kaster lys over i sin artikel om Erfaringer med vejledning $i$ studenterprojekter med eksterne samarbejdspartnere. Specielt sættes der fokus på forventningsafklaring og arbejdsdeling, så der ikke hersker tvivl om at det er de studerende som har ejerskab til projektet.

\section{Situeret vejledning}

Anette Kolmos' (professor i læring på AAU) pointe er at pege på de strukturer der omgiver projektvejledning som pejlemærker for typer af vejledning der er anvendelige. Det handler bl.a. om at identificere forskellige dimensioner i vejeledningen. Via en gennemgang af begreber som type af problembaserede projekter, idealtyper af vejledninger, faseinddeling af projektfasen, de studerendes erfaringer med projektarbejde og hvor $i$ studieforløbet de studerende befinder sig, konkluderes det at disse begrebsdifferentieringer er hjælpsomme til at situationsbestemme vejledningen så der bliver match mellem det der bliver gjort, og det de studerende har brug for.
Wichmann et al. forfølger i virkeligheden også denne pointe om nødvendigheden af at eksplicitere den matrix af begreber man forstår vejledningen ud fra. Det vil være her man kan systematisere 'hvad der virker' (noget som ofte efterlyses på kurser for vejledere om vejledning) og på den måde gøre forholdet mellem det vejleder gør, og det de studerende făr ud af indsatsen, transparent.

\section{Kriteriebaseret vejledning}

En række bidragydere til dette nummer (Per Lauvås \& Gunnar Handal, Anker Helms Jørgensen (lektor, ITU), Ken Friis Larsen \& Henning Niss, Tina Bering Keiding (studielektor, Pædagogisk Udviklingscenter, AUC), og Thomas Harboe (specialkonsulent, Pædagogisk Center Samfundsvidenskab, KU)) fremhæver at kriterier for godkendelse og bedømmelse af det produkt der vejledes på, spiller en afgørende og styrende rolle for vejledningsrelationen og for hvad der bliver en del af vejledningssamtalen eller udgrænses af den. Sammenhængen mellem fravær af kommunikerede kriterier og tillid/mistillid mellem studerende og vejledere er de centrale begreber for Thomas Harboes undersøgelse af 51 klagesager ang. vejledning og eksamen på KU og DPU. Det samme tema er vigtigt i forholdet mellem adjunkter og adjunktvejledere som Tina Bering Keiding har analyseret gennem bl.a. studier af landets adjunktpædagogikum-vejledninger og -erfaringer. Italesættelse og skriftliggørelse af kriterier for acceptable og rigtigt gode præstationer efterlyses som forudsætning for en gennemsigtig, tryg dialog hvor tilliden mellem parterne kan opretholdes også efter at karakteren er givet og udtalelsen skrevet. To væsensforskellige bud på en stillingtagen til den grundlæggende modsætning mellem vejledning og bedømmelse repræsenteres af på den ene side Thomas Harboe og Tina Bering Keiding som begge plæderer for en adskillelse af vejleder- og bedømmerroller på forskellige personer (som det kendes fra bedømmelse af $\mathrm{fx}$ mastergradsspecialer i angelsaksiske lande), og på den anden side Anker Helms Jørgensen som slår til lyd for at vejledning er bedømmelse og at kriterierne for bedømmelsen såvel som den studerendes ambitionsniveau hele tiden bør være tilstedeværende og løbende forhandles i vejledningsdialogen.

\section{Universitetet og vejledningen}

I et empirisk studie af en række vejlederes kendskab til eksisterende retningslinjer for vejledning på $\mathrm{Hu}-$ maniora, Aarhus Universitet finder Hanne Leth Andersen og Tine W. Jensen (hhv. lektor og konsulent på Center for Universitetspædagogik; AU) at kendskab hos vejledere til deres instituts retningslinjer for vejledning er begrænset. »En privatpraktiserende kultur» for vejledning, kalder forfatterne det, i hvilken fravæ- 
ret af kontekst og kollegiale fora omkring vejledning springer i øjnene. Det rejser spørgsmålet om på hvilket niveau: individ, institut, fakultet, universitet der bør skrives retningslinjer for vejledning? Det vil altid være afgørende vigtigt med den personlige udformning af enhver undervisningsaktivitet, og der vil altid være brug for hjælpsomme retningslinjer.

Universiteterne er på vej med de første erfaringer med retningslinjer på institut/fakultetsniveau, og én af fremtidens opgaver vil være udveksling af erfaringer med proaktiv forventningsstyring. I det hele er den privatpraktiserende vejleder-selvforståelse kommet under pres af modgående bevægelser: administrative og politiske bevægelser der vil fremme (kontrol med) faktorer af formodet betydning for gennemstrømning som vejledning er, behov for akkreditering af undervisning/vejledning, og minimering af klager $i$ det administrative system. Men også mange vejledere taler og skriver faktisk om et behov for kollegiale fora og netværk at drøfte vejledning i, og om ønsker om forskningsmæssigt, pædagogisk og også administrativ støtte og input til de individuelle udfordringer som vejledning - også - byder på. Inputtet kan have mange former: tilbagemeldinger fra kloge studerende og nye kandidater, retningslinjer udformet lokalt eller centralt, kurser, litteratur, supervision, kollega-sparring, institut-seminarer. Alt tyder på at den privatpraktiserende vejleder, politik og administration, og universitetspæ- dagogiske udviklinger og tilbud i de kommende år vil interagere tættere for at udvikle vejledningstilbuddet. Må de studerende også blive hørt - det er dem der skal bruge vejledningstilbuddet og tage imod det som det det er: En rigtig god mulighed for dialog om de studerendes projekter, på præmisser som er både de studerendes, vejledernes og universiteternes - $i$ hele deres videnskabelige og politisk/administrative kontekst.

Grundlæggende synes vi i redaktionen at vi har fảet samlet en fin buket af artikler som i bredt spektrum af fag og forholdemåder får lagt ved til den viden vi har om vejledning. Interessen for at være med i refleksioner og videndeling har, som det tydeligt ses af tidsskriftets omfang denne gang, også medført at det næsten er blevet en hel lille antologi.

\section{Referencer}

Bjerrum, Christian, Ellegaard, Marianne \& Nielsen, Lars (2003): De studerendes motivation bag valget af speciale. Center for Naturfagenes Didaktik, Københavns Universitet.

Harboe, Thomas \& von Müllen, Rikke (2006): De studerendes forventninger til specialevejledning - en sporgeskemaundersøgelse på Det Samfundsvidenskabelige Fakultet og Det Juridiske Fakultet. Københavns Universitet. 